\title{
Ouro Preto foi, no passado mês de maio, a capital de inovação em tecnologia da soldagem!
}

A inovação tecnológica é um fator importante no crescimento econômico de uma sociedade. Inovar em tecnologia de soldagem passa por desenvolver processos mais eficientes, capazes de soldar materiais "novos" e "amigos do ambiente".

Desde a invenção do elétrodo revestido por Oscar Kejllberg, no início do século XX até os nossos dias, a investigação e desenvolvimento em soldagem gerou muitas dezenas de processos inovadores. Hoje em dia é impensável, por exemplo, construir um reservatório de pressão soldado com o processo por elétrodos revestidos. Com outros processos obtém-se maior produtividade, mais qualidade, construindo-se melhor e com custo mais baixo.

Vivendo-se na era das tecnologias de comunicação, num mercado cada vez mais exigente, que solicita soluções novas, mais eficientes e mais econômicas, é de senso comum procurar tirar partido de experiências vividas para melhorar os processos de investigação e desenvolvimento e de transferência de tecnologia. Este é um dos objetivos do IIW (International Institute of Welding), que conta com a participação de 53 países e atua como um motor para integrar mundialmente o trabalho que se faz em tecnologia de soldagem e afins.

Uma das formas utilizadas pelo IIW para desenvolver e disseminar conhecimento são as suas Comissões Técnicas, que juntam especialistas do mais alto nível mundial nos vários tópicos ligados à soldagem e técnicas afins. $\mathrm{O}$ Study Group RES (Welding research strategy and collaboration) é um destes grupos técnicos, cuja missão é promover a colaboração entre os pesquisadores nos 53 países do IIW.

O Study Group RES, na sua reunião de julho de 2010 em Istambul, propôs uma aproximação diferente para incentivar a transferência de conhecimento entre as várias regiões do mundo através da organização de "Schools of Welding and Correlated Processes".

O primeiro destes eventos, o "I European-South American School of Welding and Correlated Processes", foi realizado em maio de 2011, juntando em Ouro Preto, cerca de 70 investigadores convidados da Europa e da América Latina para fazer um exercício de "bench marking" no que respeita à investigação e desenvolvimento em Soldagem e Técnicas Afins nos dois continentes.

Discutiu-se temas, metodologias, objetivos a atingir, transferência de resultados para a indústria e muitos outros aspectos. Em dois dias de trabalho intenso, descobriu-se interesses comuns, criou-se parcerias e definiu-se projetos de cooperação de modo a maximizar os resultados para ambas as regiões. Surpreendeu a Europa a pujança do Brasil e o desafio posto pelas necessidades técnicas a curto prazo em obras diversas espalhadas pelo país.

Neste primeiro "Welding School" foram estabelecidas parcerias entre pesquisadores brasileiros, argentinos e europeus para o desenvolvimento de trabalhos de investigação, desenvolvimento e inovação em áreas tão diversas como a metalurgia da soldagem, a análise de fumos e o desenvolvimento de sensores.

$\mathrm{O}$ evento incluiu um programa social que proporcionou agradáveis momentos de confraternização, nos quais a simpatia brasileira pontuou e onde se experimentou deliciosos pratos típicos degustados em ambientes acolhedores, permitindo aos Europeus desfrutar as típicas caiprinhas (em quantidade e, consequentemente..., familiarizarem-se com o seu efeito!).

O sucesso do evento gerou vários convites para a realização de uma segunda reunião que ficou agendada para o ano de 2012, na Áustria, a convite da empresa Fronius.

Profa. Luisa Quintino 